\title{
SPIRIT TA'AWUN DALAM STRATEGI PEMASARAN PEDAGANG PASAR BESAR KOTA PALANGKA RAYA
}

\author{
Novi Angga Safitri ${ }^{\mathrm{a}, 1}$ \\ ${ }^{a}$ Institut Agama Islam Negeri Palangka Raya, Palangka Raya 73112, Indonesia \\ ${ }^{I}$ novianggasafitri@gmail.com
}

\begin{tabular}{|c|c|}
\hline ARTICLE INFO & ABSTRACT \\
\hline $\begin{array}{l}\text { Article history: } \\
\text { Received : 2021-04-30 } \\
\text { Revised : 2021-06-21 } \\
\text { Accepted : 2021-06-23 }\end{array}$ & \multirow[b]{2}{*}{$\begin{array}{l}\text { In the practice of Ta'awun, the traders of Pasar Besar at Palangka } \\
\text { Raya City performed it by helping each other in providing and } \\
\text { selling the goods needed by buyers, as well as to other fellow } \\
\text { traders. However, there were still some traders who did not help } \\
\text { each other with other traders because they thought there was } \\
\text { business competition. This study attempted to determine the form and } \\
\text { constraints of the implementation of Ta'awun spirit of the traders } \\
\text { marketing strategy. The form of implementation of the Ta'awun } \\
\text { Spirit in Pasar Besar traders at Palangka Raya City was to apply the } \\
\text { P4 concept, namely: Product, Price, Place, and Promotion. The } \\
\text { obstacles to the implementation of the Ta'awun Spirit of Pasar Besar } \\
\text { traders at Palangka Raya City were divided into two, namely: (a) } \\
\text { from the traders' perspective, the problem was that sometimes there } \\
\text { were traders who did not give their wares to other traders for resale. } \\
\text { In addition, in terms of price sometimes it was not in accordance } \\
\text { with the agreement. When other traders want to sell their goods. } \\
\text { They sold goods to fellow traders with a price higher than the market } \\
\text { price. (b) From the buyers' side, when the desired product has been } \\
\text { provided, and the item was already existed, the buyers suddenly } \\
\text { cancelled without unclear reasons and sometimes impatient, so that } \\
\text { they just left when the item is being looked for. } \\
\text { ABSTRAK }\end{array}$} \\
\hline $\begin{array}{l}\text { Keywords: } \\
\text { Ta'awun } \\
\text { Marketing Strategy } \\
\text { Traders }\end{array}$ & \\
\hline $\begin{array}{l}\text { Kata kunci: } \\
\text { Ta'awun } \\
\text { Strategi Pemasaran } \\
\text { Marketing Mix }\end{array}$ & $\begin{array}{l}\text { Dalam praktek Ta'awun, pedagang Pasar Besar Kota Palangka Raya } \\
\text { melakukannya dengan saling tolong-menolong dalam mengadakan } \\
\text { dan menjual barang-barang yang dibutuhkan oleh pembeli, selain itu } \\
\text { juga kepada sesama pedagang lainnya. Namun demikian, masih ada } \\
\text { sebagian pedagang yang tidak mau saling tolong-menolong dengan } \\
\text { pedagang lainnya karena menganggap adanya persaingan usaha. } \\
\text { Penelitian ini bertujuan untuk mengetahui bentuk dan kendala } \\
\text { implementasi spirit Ta'awun dalam strategi pemasaran pedagang. } \\
\text { Bentuk implementasi Spirit Ta'awun dalam Strategi Pemasaran } \\
\text { Pedagang Pasar Besar Kota Palangka Raya adalah dengan } \\
\text { menerapkan konsep 4P yaitu: Product, Price, Place, dan Promotion. } \\
\text { Kendala Implementasi Spirit Ta'awun dalam Strategi Pemasaran } \\
\text { Pedagang terbagi menjadi dua yaitu: Dari sisi pedagang kendalanya } \\
\text { adalah terkadang ada pedagang yang tidak mau memberikan } \\
\text { dagangannya kepada pedagang lain untuk dijual kembali, selain itu } \\
\text { dari segi harga terkadang tidak sesuai dengan kesepakatan, ketika } \\
\text { pedagang lainnya hendak menjual barangnya kepada sesama } \\
\text { pedagang malah dengan harga yang lebih tinggi dari harga pasaran. } \\
\text { Dari sisi pembeli yaitu ketika sudah dicarikan produk yang } \\
\text { diinginkan sebelumnya namun ketika barang sudah ada pembeli } \\
\text { tersebut tiba-tiba beralasan tidak jelas dan terkadang tidak sabar } \\
\text { sehingga pergi begitu saja ketika barang sedang dicarikan. }\end{array}$ \\
\hline
\end{tabular}




\section{Pendahuluan}

Penelitian ini berlatarbelakang tentang kehidupan Pedagang Pasar Besar Kota Palangka Raya yang melakukan praktek Ta'awun atau saling membantu (tolongmenolong) dalam berdagang. Selain tolongmenolong kepada pembeli dengan cara mengadakan dan menjual barang-barang yang dibutuhkan oleh pembeli, ada pula pedagang yang juga saling tolong-menolong kepada sesama pedagang lainnya. Pada prakteknya pedagang pasar di kota Palangka Raya sebagiannya memang saling membantu dan tolong-menolong, namun demikian kenyataannya di lapangan masih ada sebagian pedagang yang tidak mau saling tolong-menolong dengan pedagang lainnya, bahkan menganggap adanya persaingan usaha. Pedagang tersebut hendak menjual barangnya sendiri langsung kepada pembeli tanpa mau barangnya diambil dan dibeli oleh pedagang lainnya untuk dijual kembali ke pembeli. Penelitian ini bertujuan untuk mengetahui bentuk implementasi spirit Ta'awun dalam strategi pemasaran pedagang Pasar Besar Kota Palangka Raya, serta menganalisis kendala implementasi spirit Ta'awun dalam strategi pemasaran pedagang Pasar Besar Kota Palangka Raya.

\section{Tinjauan Pustaka}

\section{Spirit Ta'awun}

Kata spirit menurut Kamus Besar Bahasa Indonesia berarti semangat, jiwa, sukma dan juga roh. Sedangkan semangat berarti roh kehidupan yang menjiwai segala makhluk, baik hidup maupun mati (menurut kepercayaan orang dulu dapat memberikan kekuatan). Jadi spirit atau semangat dapat diartikan sebagai sikap yang mendasari tindakan manusia.

Kata Ta'awun berasal dari kata Ta'awana, Yata'aawuna, Ta'awuna dalam Bahasa Arab yang artinya tolong-menolong, gotong-royong, bantu membantu sesama manusia. Dalam Islam Ta'awun menjadi dasar utama bagi seorang muslim untuk senantiasa bersikap tolong-menolong sesama muslim lainnya (Sjaiful, 2014). Allah SWT berfirman:

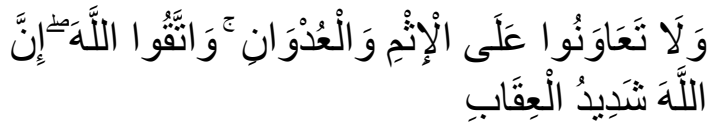

Artinya: "Dan tolong-menolonglah kamu dalam (mengerjakan) kebajikan dan takwa, dan jangan tolong-menolong dalam berbuat dosa dan pelanggaran. Dan bertakwalah kamu kepada Allah, sesungguhnya Allah amat berat siksa-Nya. (Q.S. Al-Ma'idah [5]:2)

Ayat di atas tidak hanya berisi tentang perintah untuk melakukan tolong-menolong dalam hal kebaikan namun juga berisi tentang larangan melakukan tolongmenolong dalam hal melakukan keburukan atau kejahatan. Sebagaimana kita ketahui bahwa tidak semua bentuk tolong- menolong itu baik, melainkan ada pula yang tidak baik. Tolong-menolong yang baik ialah apabila mengarah kepada kebaikan dan ketaqwaan kepada Allah SWT, sedangkan tolongmenolong dalam hal keburukan atau kejahatan yakni berkaitan dengan masalah dosa, permusuhan serta hal-hal lain yang dilarang oleh agama (Khoiruddin, 2018). Tolong menolong boleh dilakukan kepada siapa saja termasuk dengan non muslim, selama hal tersebut tidak terkait dengan masalah akidah dan ibadah.

Menurut hemat penulis hubungan antara spirit atau semangat dengan Ta'awun diartikan sebagai semangat tolong-menolong yang sangat penting untuk dimiliki oleh semua orang dalam hal ini pedagang. Karena jika seorang pedagang memiliki spirit Ta'awun pada dirinya maka pedagang tersebut akan melakukan usaha perdagangan tidak hanya beriorientasi untuk mencari keuntungan semata namun juga bertujuan untuk saling tolong-menolong untuk membantu menyediakan barang-barang kebutuhan pembeli juga tolong-menolong dalam hal menyediakan barang dan berbagi keuntungan dengan para pedagang lainnya.

\section{Strategi Pemasaran}

Pemasaran adalah kegiatan terpenting dalam kehidupan perusahaan sebagai usaha untuk mencapai tujuan perusahaan, mengembangkan usaha, mendapatkan laba serta untuk mempertahankan kelangsungan hidup perusahaan tersebut. Keberhasilan 
suatu usaha sangat bergantung pada keahlian manajemen serta keahlian pada bidang pemasaran dari produk yang diproduksi. Setiap usaha baik yang bergerang di bidang produk maupun jasa mempunyai tujuan untuk tetap hidup dan berkembang. Tujuan tersebut dapat terealisasikan melalui upaya untuk dapat mempertahankan dan meningkatkan keuntungan atau laba operasional suatu usaha (Rusmadi, 2016). Oleh karena itu setiap perusahaan harus memiliki strategi untuk memasarkan produk maupun jasa yang diproduksi.

Menurut Alma strategi pemasaran berarti memilih dan menganalisa pasar sasaran yang merupakan suatu kelompok orang yang ingin dicapai oleh perusahaan atau usaha menciptakan bauran pemasaran yang cocok dan dapat memuaskan pasar sasaran tersebut (Alma, 2008). Sedangkan menurut Assauri strategi dalam Retina pemasaran adalah serangkaian tujuan dan sasaran, kebijakan serta aturan yang mengarahkan usaha-usaha pemasaran perusahaan dari waktu ke waktu pada masing-masing tingkatan dan acuan serta lokasinya, terutama sebagai respon perusahaan dalam menghadapi lingkungan pesaing yang selalu berubah (Sedjati, 2015). Jadi yang dimaksud dengan strategi pemasaran adalah upaya memasarkan suatu produk baik berupa barang maupun jasa dengan menggunakan rencana tertentu untuk meningkatkan jumlah penjualan serta agar mampu selalu bersaing dengan para pesaing.

Setiap perusahaan atau pengusaha yang ingin produknya diterima oleh pasar sasaran memerlukan strategi pemasaran. Setiap perusahaan atau pengusaha dapat meningkatkan penjualan produknya dengan menggunakan strategi pemasaran yang efektif untuk meningkatkan pangsa konsumen yang ada. Strategi pemasaran yang dapat digunakan perusahaan antara lain: STP (Segmentasi, Targeting, Positioning) dan bauran pemasaran. Bauran pemasaran atau biasa disebut marketing mix adalah kumpulan variabel dalam pemasaran, yang dapat diatur untuk mencapai tujuan pemasaran, yaitu memenuhi kebutuhan pelanggan dan memaksimalkan keuntungan. Menurut Kotler, bauran pemasaran sering disebut dengan istilah 4P yaitu Product (Produk), Price (Harga), Place (Tempat), dan Promotion (Promosi).

\section{Etika Bisnis Islam}

Islam memandang pasar sebagai tempat yang legal, halal dan ideal untuk berbisnis. Meski bersaing, pasar syariah tetap sarat dengan nilai-nilai Islam seperti keadilan, keterbukaan, kejujuran, dan persaingan yang sehat. Ibnu Taimiyah menyebutkan bahwa pasar syariah memiliki beberapa ciri atau ciri, antara lain: setiap orang dapat dengan bebas masuk dan keluar pasar, tidak ada monopoli, informasi yang cukup, tidak ada sumpah palsu, penipuan dosis dan tidak ada penjualan barang selundupan. Ajaran Islam menjunjung tinggi kebebasan pribadi, tetapi dibatasi oleh nilai-nilai hukum Syariah, yang mengarah pada kerjasama daripada persaingan yang mematikan.

Secara epistemologi, kata Etika berasal dari kata Yunani ethos. Ethos berarti tempat tinggal, padang rumput, kandang, kebiasaan, adat istiadat, kepribadian, perasaan, sikap dan cara berpikir. Bentuk jamaknya adalah tha etha, yang berarti adat. Secara etimologis, etika mengacu pada ilmu tentang tingkah laku yang biasanya berkaitan dengan ketaatan terhadap ketertiban, adat istiadat, dan kehidupan yang baik dan buruk. Adapun Imam An-Nawawi dalam kitabnya Syarah Riyadhus Shalihin mengatakan bahwa akhlak atau adab adalah cara berperilaku seseorang.

Integrasi etika Islam dalam bisnis telah menciptakan paradigma bisnis dalam sistem etika bisnis Islam. Paradigma bisnis adalah seperangkat pemikiran atau sudut pandang tertentu yang menjadi landasan bisnis, baik sebagai aktivitas maupun sebagai entitas. Paradigma bisnis Islam didirikan dan didasarkan pada aksioma berikut: kesatuan, keadilan, kehendak bebas, tanggung jawab dan kebenaran (kebaikan dan kejujuran).

\section{Metodologi Penelitian}

Jenis penelitian ini adalah penelitian kualitatif dengan menggunakan pendekatan kualitatif deskriptif, pendekatan fenomenologis dan pendekatan kontekstual ekonomi syariah. Penelitian ini berlokasi di Komplek Pasar Besar Kota Palangka Raya yang beralamat di Jl. Ahmad Yani, Palangka Raya, Provinsi Kalimantan Tengah. Subjek dalam penelitian ini adalah para pedagang di Pasar Besar Kota Palangka Raya. Sedangkan objek penelitian ini Spirit Ta'awun dalam Strategi Pemasaran Pedagang Pasar Besar 
Kota Palangka Raya. Pengumpulan data dalam penelitian ini menggunakan tiga metode yaitu: observasi, wawancara dan juga dokumentasi. Teknik pengabsahan data menggunakan triangulasi data dan sumber sedangkan untuk menganalisis data menggunakan teknik Collections, Display data, Coclusions drawing, dan Verifikasi.

\section{Hasil dan Diskusi}

Hasil analisis penelitian Spirit Ta'awun dalam Strategi Pemasaran pedagang Pasar Besar Kota Palangka Raya akan peneliti uraikan menjadi dua sub bab pembahasan kajian utama sesuai dengan rumusan masalah, yaitu: Bentuk Implementasi Spirit Ta'awun dalam Strategi Pemasaran Pedagang Pasar Besar Kota Palangka Raya serta Kendala Implementasi Spirit Ta'awun dalam Strategi Pemasaran Pedagang Pasar Besar Kota Palangka Raya.

\section{Bentuk Implementasi Spirit Ta'awun dalam Strategi Pemasaran Pedagang Pasar Besar Kota Palangka Raya}

Spirit Ta'awun adalah spirit atau semangat dengan Ta'awun diartikan sebagai semangat tolong-menolong yang sangat penting untuk dimiliki oleh semua orang dalam hal ini pedagang. Karena jika seorang pedagang memiliki spirit Ta'awun pada dirinya maka pedagang tersebut akan melakukan usaha perdagangan tidak hanya beriorientasi untuk mencari keuntungan semata namun juga bertujuan untuk saling tolong-menolong kepada pembeli maupun kepada sesama pada pedagang lainnya. Perintah berikap Ta'awun dimuat dalam Surah Al-Maidah ayat 2 yang berisi anjuran untuk tolong-menolong antar sesama, di dalam ayat tersebut juga berisi larangan untuk melakukan tolong-menolong dalam hal keburukan ataupun maksiat.

Pada pembahasan sebelumnya telah dipaparkan bahwa salah satu strategi pemasaran ialah strategi bauran pemasaran atau biasa disebut dengan istilah marketing mix. Marketing mix adalah variabel-variabel pemasaran yang bisa diatur sedemikian rupa agar dapat memenuhi kebutuhan maupun keinginan pelanggan dan untuk mencapai tujuan dari sebuah pemasaran. Variabelvariabel tersebut terdiri dari 4P, yaitu
Product (Produk), Price (Harga), Place (Tempat) dan Promotion (Promosi).

Bentuk Implementasi Spirit Ta'awun dalam Strategi Pemasaran Pedagang Pasar Besar Kota Palangka Raya adalah sebagai berikut:

\section{a. Product (Produk)}

Product (produk) merupakan suatu bentuk yang ditawarkan oleh organisasi ataupun perusahaan untuk terciptanya tujuan perusahaan melalui kebutuhan dan keinginan konsumen. Sebuah produk ditawarkan melalui suatu pasar yang bertujuan agar produk bisa dilihat, diperhatikan, diperoleh, digunakan serta dikonsumsi sesuai dengan kebutuhan konsumen yang berupa barang ataupun jasa. Produk merupakan hasil dari proses produksi yang akan dijual oleh perusahaan atau dibeli perusahaan untuk dipasarkan kembali kepada konsumen (Rusmadi, 2016). Jadi yang dimaksud produk adalah suatu hal baik berupa barang atau benda ataupun jasa yang ditawarkan oleh penjual kepada calon pembeli.

Produk yang ditawarkan dan dijual oleh para pedagang di Pasar Baru Besar Kota Palangka Raya yang menjadi subjek dalam penelitian ini sangat bervariasi, seperti Pedagang KH yang menjual karpet, sprey, bantal, guling, taplak meja, kelambu, selimut, sarung dan lain-lain. Pedagang RR yang selain berprofesi sebagai penjahit juga menjual berbagai macam gorden beserta perlengkapannya seperti batang gorden, tirai, tali dan lain-lain. Adapula Pedagang RA yang berjualan ranjang, kain, gorden, kapuk, dacron bahkan juga pecah-belah. Sedangkan Pedagang NA berjualan springbed, Kasur busa, Kasur kapuk dan juga perlengkapan bayi. Pedagang MI berjualan karpet, tikar, sajadah masjid, sejadah biasa, mukena dan lain-lain. Adapun jika dilihat dari model, bentuk dan juga kualitas produk yang dijual oleh masing-masing Pedagang di Pasar Besar Kota Palangka Raya pun bermacam-macam, ada yang kualitas standar atau biasa sampai dengan yang kualitasnya sangat bagus.

Bentuk implementasi spirit Ta'awun dalam product yang dijual oleh para Pedagang Pasar Besar Kota Palangka Raya ialah dengan menyediakan berbagai macam produk yang merupakan kebutuhan maupun 
keinginan pembeli dan jika barang yang dicari oleh pembeli sedang habis ataupun kosong maka pedagang sedapat mungkin akan membantu mencarikan produk (barang) tersebut ke toko pedagang lain dengan tujuan untuk membantu pembeli agar tidak repot mencari-cari barang tersebut serta untuk membantu menjualkan barang pedagang lainnya.

Bentuk implementasi spirit Ta'awun dalam product terlihat dari hasil wawancara dengan Pedagang $\mathrm{KH}$ yang menyebutkan bahwa jika pembeli mencari produk yang sedang kosong di tokonya maka dirinya akan mencarikan product tersebut ke toko pedagang lain asalkan pembeli bersedia menunggu (KH, 2020). Hal tersebut Pedagang KH lakukan agar pembeli tidak susah mencari ke tempat pedagang lain dan untuk membantu menjualkan barang pedagang lain. Begitu pula dengan Pedagang/Penjahit RR yang mencarikan pula product yang dicari oleh pembeli ke toko pedagang lain jika pembeli mencari product dengan motif tertentu atau jika di tokonya sedang kekurangan stok barang, misal pembeli mau membeli 12 item barang sedagkan stok di tokonya hanya ada 10, maka kekurangannya akan dicarikan ke toko pedagang lain. Hal tersebut dilakukan untuk membantu melengkapi barang yang dibutuhkan oleh pembeli.

Pedagang RA menjelaskan bahwa dalam hal mengadakan barang yang diinginkan pembeli pun seringkali mencarikan product tersebut ke toko pedagang lain dengan alasan terkadang pembeli menginginkan kualitas product yang lebih bagus sedangkan yang ada di tokonya kualitasnya standar atau bahkan bisa juga sebaliknya. Selain itu Pedagang RA juga menambahkan bahwa dirinya melakukan hal tersebut untuk memenuhi permintaan pembeli dan untuk membantu menjualkan barang dagangan pedagang lain agar sama-sama mendapatkan keuntungan.

Pedagang NA juga melakukan hal sama dengan Pedagang $\mathrm{KH}$, RR dan juga RA dengan alasan terkadang pembeli minta carikan product langsung satu paket, misalnya seperti perlengkapan bayi dimulai dari perlengkapan tidur sampai dengan pakaian. Pedagang NA melakukan hal tersebut untuk membantu melengkapi belanjaan (kebutuhan) pembeli. Begitu pula dengan Pedagang MI yang mengaku sering mencarikan product yang diinginkan oleh pembeli ke toko pedagang lain dengan alasan untuk menyesuaikan dengan selera maupun kebutuhan dan keinginan pembeli terhadap product tertentu. Pernyataan subjek penelitian sejalan dengan pernyataan dari informan yaitu para pembeli yang menyatakan bahwa mereka merasa sangat terbantu ketika pedagang mau mencarikan barang yang sedang mereka cari ke pedagang lain sehingga mereka tidak perlu repot-repot mencari sendiri barang yang mereka butuhkan dan inginkan tersebut.

\section{b. Price (Harga)}

Price (Harga), menurut Kotler dalam Dewi adalah nilai yang diperlukan konsumen untuk suatu manfaat atas pengkonsumsian, penggunaan ataupun kepemilikan barang atau jasa. Harga merupakan salah satu faktor yang harus dikendalikan secara serasi, selaras dengan tujuan yang ingin dicapai oleh perusahaan. Segala keputusan yang menyangkut dengan harga akan sangat mempengaruhi beberapa aspek kegiatan suatu usaha baik yang menyangkut kegiatan penjualan ataupun aspek keuntungan yang ingin dicapai oleh suatu lini usaha. Ini berarti harga menggambarkan nilai uang sebuah barang atau jasa (Pane, 2018). Sederhananya harga adalah nilai tukar suatu product yang dinyatakan dalam bentuk uang.

Daya beli konsumen menjadi salah satu pertimbangan dalam menentukan harga sebuah produk. Hal ini dikarenakan bagi sebagian besar masyarakat harga masih menjadi faktor pertimbangan utama sebelum memutuskan untuk membeli sebuah produk ataupun jasa. Bagi pedagang/penjual yang terpenting ialah bagaimana menetapkan harga yang pantas, terjangkau oleh masyarakat dan tidak merugikan perusahaan. Sedangkan bagi pembeli biasanya menginginkan produk dengan harga yang murah namun dengan kualitas yang bagus. Itulah salah satu alasan mengapa banyak masyarakat yang senang membeli di pasar tradisional, karena di pasar tradisional masih memungkinkan adanya tawar menawar antara pedagang dan juga pembeli sampai dengan terjadinya kesepkatan harga. Dalam strategi bauran pemasaran pada aspek price 
atau harga, selain berhubungan dengan pemberian nilai suatu barang dalam bentuk uang atas suatu produk serta dinilai pula dari segi kemudahan dalam sistem pembayaran yang dilakukan oleh konsumen.

Penentuan harga yang ditetapkan oleh para Pedagang di Pasar Besar Kota Palangka Raya ialah sesuai dengan harga pasaran dan sesuai dengan kesepakatan antara pedagang dan pembeli yang diawali dengan proses tawar menawar. Bentuk implementasi spirit Ta'awun dalam Price (harga), ialah dengan memberikan harga yang terjangkau atau sesuai dengan harga pasaran meskipun barang yang dijualkan merupakan barang yang dibeli dari pedagang lainnya jadi secara otomatis keuntungan yang didapatkan hanya sedikit. Bahkan ada pula pedagang yang rela tidak mengambil keuntungan sama sekali sebagai bentuk tolong-menolong kepada pembeli dan pedagang lainnya.

Bentuk implementasi spirit Ta'awun tersebut dalam aspek harga untuk lebih jelasnya dapat dilihat dari hasil wawancara peneliti yaitu tiga dari lima subjek dalam penelitian ini yaitu Pedagang RR, RA, dan NA menyatakan bahwa terkadang ada pula pedagang lain yang memberikan barang kepada mereka untuk dijual lagi namun harganya sama dengan harga pasaran atau pun seharga dengan kesepakatan antara pedagang dan pembeli, ketika hal itu terjadi mereka rela saja menjual barang ke pembeli tanpa mengambil keuntungan sedikit pun dengan alasan yang penting barang mereka sendiri pun laku dan mereka sudah merasa cukup puas dengan hasil keuntungan dari penjualan barang mereka sendiri tersebut. Sedangkan hasil penjualan barang pedagang lain yang tanpa keuntungan itu mereka mengaku tidak mempermasalahkannya karena berniat membantu melengkapi kebutuhan pembeli dan untuk membantu menjualkan barang dagangan pedagang lain. Pernyataan subjek penelitian sejalan dengan pernyataan dari informan yaitu para pembeli yang menyatakan bahwa mereka merasa sangat terbantu ketika pedagang mau mencarikan barang yang sedang mereka cari ke pedagang lain karena dari segi harga pun lebih murah atau sama dengan harga pasaran dibandingkan ketika mereka mencari sendiri ke toko pedagang lain apalagi ketika barang yang mereka cari tersebut sedang langka di pasaran.

\section{c. Place (Tempat)}

Place (tempat/lokasi) menurut Alfidatun dalam Syahrial berarti tempat perusahaan jasa/produk harus bermarkas dan melakukan aktivitas kegiatannya. Lokasi yang strategis, nyaman dan mudah dijangkau akan menjadi daya tarik tersendiri bagi pelanggan (Labaso, 2018). Ada tiga jenis interaksi yang mempengaruhi lokasi, yaitu: Pertama Konsumen mendatangi pemberi jasa (perusahaan): apabila keadaannya seperti ini maka lokasi menjadi sangat penting, Kedua Pemberi jasa mendatangi konsumen: dalam hal ini, lokasi tidak terlalu penting, tetapi yang harus diperhatikan adalah penyampaian jasa harus tetap berkualitas, Ketiga Pemberi jasa dan konsumen tidak bertemu secara langsung: berarti penyedia layanan/jasa (service provider). Dan konsumen berinteraksi melalui sarana tertentu seperti telepon, komputer, atau surat. Ada beberapa indikator lokasi yaitu: Mudah dijangkau sarana transportasi umum, lalu lintas banyak dilalui orang, tempat parkir yang luas dan aman, lingkungan sekitar yang aman dan juga nyaman, dekat dengan fasilitas umum yang lain dan lokasi berada di jalan utama Kota (Supriyanto \& Taali, 2018).

Bentuk implementasi spirit Ta'awun dalam Place (Tempat) dengan melakukan transaksi penjualan di toko pedagang. Jadi ketika barang yang dicari pembeli kosong maka pedagang tersebut yang akan mencarikan ke pedagang lainnya, sedangkan pembeli cukup menunggu saja ketika barang dicarikan. Pada saat barang sudah didapatkan pedagang akan membawakan barang tersebut ke pembeli yang menunggu, sehingga tempat proses transaksi jual beli tetap berlangsung di toko si pedagang awal. Dalam hal ini iinforman yaitu para pembeli merasa tempat atau lokasi terjadinya transaksi jual beli antara pembeli dan pedagang menjadi lebih mudah karena pembeli tidak perlu mencaricari barang yang ia butuhkan ke toko lainnya tetapi hanya perlu menunggu si pedagang mencarikan barang yang dimaksud.

\section{d. Promotion (Promosi)}

Promotion (Promosi) menurut Soetojo dalam Dayat adalah kegiatan untuk memperkenalkan produk, meyakinkan pembeli dengan harapan akan tergerak hatinya dan secara sukarela membeli produk 
tersebut. Promosi merupakan salah satu faktor penentu keberhasilan suatu program pemasaran. Betapapun berkualitasnya suatu produk atau jasa, bila konsumen belum pernah mendengarnya dan tidak yakin bahwa produk atau jasa tersebut akan berguna bagi mereka, maka mereka tidak akan pernah membelinya. Tujuan utama dari promosi adalah menginformasikan, mempengaruhi, membujuk serta mengingatkan konsumen sasaran tentang perusahaan dan bauran pemasarannya (Dayat, 2019).

Bentuk implementasi spirit Ta'awun dalam Promotion (promosi), dengan cara menyampaikan kelebihan maupun kekurangan barang yang diperjualbelikan selain itu pedagang tidak hanya mempromosikan maupun memasarkan dagangannya sendiri tetapi juga membantu mempromosikan dagangan pedagang lain sebagai langkah untuk saling bekerja sama dan tolong-menolong sesama para pedagang dan juga kepada para pembeli.

Pedagang Pasar Besar Kota Palangka Raya dalam memasarkan produknya yaitu dengan cara menawarkannya secara langsung kepada calon pembeli yang lewat di depan toko mereka masing kemudian ketika calon pembeli singgah ke toko si pedagang maka pedagang tersebut akan memperkenalkan produknya kepada calon pembeli. Dalam melakukan kegiatan promosinya dilakukan secara jujur dan tidak ada unsur melebihlebihkan sehingga tidak ada unsur penipuan di dalamnya. Dengan prinsip kejujuran maka pembeli tidak akan takut jika barang yang dibeli tidak sesuai dengan yang dipromosikan.

Berdasarkan hasil wawancara kepada para subjek penelitian baik narasumber dan juga informan diketahui bahwa jenis komunikasi pemasaran yang digunakan oleh Pedagang Pasar Besar Kota Palangka Raya dalam memasarkan produknya ialah dengan cara Personal Selling (Penjualan Langsung) yaitu komunikasi langsung (tatap muka) antara penjual dengan calon pembeli untuk memperkenalkan suatu produk dan membentuk pemahaman pembeli terhadap produk sehingga kemudian pelanggan akan memutuskan untuk mencoba dan membeli produk tersebut. Selain Personal Selling metode komunikasi lain yang digunakan oleh Para Pedagang Pasar Besar Kota Palangka Raya ialah dengan metode Sales Promotion
(Promosi Penjualan) yaitu memberikan potongan harga kepada para pembeli yang membeli product dengan jumlah banyak ataupun kepada pembeli yang sudah menjadi langganan di toko masing-masing pedagang terlebih ketika pembeli bermaksud untuk menjual kembali barang yang dibeli tersebut.

Perdagangan merupakan salah satu cara untuk memperoleh penghasilan dalam hal memenuhi kebutuhan hidup manusia. Bahkan disebutkan sembilan dari sepuluh pekerjaan di dunia ini ialah sebagai pedagang. Rasulullah SAW pun selain sebagai panglima perang juga berprofesi sebagai pedagang yang sangat sukses di masanya. Islam mengakui peranan perdagangan untuk mendapatkan keberuntungan serta kebesaran. Namun Islam membatasi cara mendapatkan keuntungan dan kebesaran tersebut dengan tidak melakukan kezaliman terhadap sesama terutama dalam berbisnis yang harus dilakukan dengan suka sama suka.

Salah satu kondisi yang harus dihilangkan agar dapat menciptakan sikap saling ridha adalah terbebasnya transaksi jual beli tersebut dari unsur penipuan. Dalam hal ini, Pedagang RA dalam keterangan wawancaranya menyampaikan bahwa salah satu etika bisnis dalam berdagang yang diketahui ialah harus sepakat terkait masalah harga dalam artian rela sama rela. Hal tersebut dilakukan untuk menimbulkan rasa saling ridha antar penjual dan juga pembeli (RA, 2020).

Perasaan saling ridha dalam transaksi jual beli selain muncul karena adanya kesepakatan harga juga terjadi karena adanya sikap keterbukaan yang disampaikan oleh si Pedagang. Terintegrasinya etika Islam dalam bisnis telah menciptakan suatu paradigma bisnis dalam sistem etika bisnis Islam. Paradigma bisnis adalah gugusan pikir atau cara pandang tertentu yang dijadikan sebagai landasan bisnis baik sebagai aktivitas maupun sebagai entitas. Paradigma bisnis Islam dibangun dan dilandasi oleh aksiomaaksioma berikut:

\section{1) Kesatuan (Tauhid)}

Berdasarkan konsep Beekun juga Yusuf, seorang pelaku bisnis Muslim dalam melakukan kegiatan berbisnisnya tidak akan melakukan paling tidak tiga hal: Pertama diskriminasi diantara pekerja, penjual, pembeli, mitra kerja atas dasar pertimbangan ras, warna kulit, jenis kelamin atau agama. 
Kedua terpaksa atau dipaksa melakukan praktek-prektek mal-bisnis karena hanya Allah-lah yang semestinya ditakuti dan dicintai. Ketiga menimbun kekayaan atau serakah, karena hakikatnya kekayaan merupakan amanah Allah SWT.

Para Pedagang Pasar Besar Kota Palangka Raya pada kenyataannya telah menjalankan aksioma etika bisnis islam tentang Ketauhidan, Hal ini terlihat dari hasil wawancara peneliti kepada beberapa yang menyebutkan bahwa: Pedagang MI menyebutkan bahwa salah satu etika bisnis yang diketahui ialah tidak boleh mendiskriminasikan para pembeli dalam artian siapa pun calon pembeli yang mampir di tokonya harus dilayani dengan sebaik mungkin tanpa memandang status sosial, jenis kelamin, usia, agama dan lain sebagainya (MI, 2020). Pedagang NA dan RR juga menyebutkan bahwa tidak boleh menjual sesuatu yang dilarang, yakni produk atau jasa yang dilarang dalam agama maupun hukum yang berlaku di Kota Palangka Raya pada khususnya (NA, 2020; RR, 2020). Selanjutnya Pedagang KH juga menyebutkan bahwa antar sesama pedagang harus saling membantu jika pedagang lainnya sedang kehabisan barang dan bermaksud untuk mengambil barang di tokonya, alasannya bahwa suatu saat bisa jadi dirinya melakukan hal sama. Artinya beranggapan bahwa dalam berbisnis perlu namanya kerjasama antar pedagang jangan hanya mau menang sendiri (KH, 2020). Terlihat bahwa pada prakteknya Para Pedagang Pasar Besar Kota Palangka Raya telah memahami dan juga menerapkan tentang aksioma Etika Bisnis Islam tentang Kesatuan (Tauhid) baik dari segi tidak melakukan diskriminasi, tidak menjual barang yang diharamkan, serta tidak bersikap serakah.

\section{2) Keadilan}

Keadilan atau biasa juga disebut dengan keseimbangan, kebersamaan, dan kemoderatan merupakan prinsip etis yang harus diterapkan dalam aktivitas maupun entitas bisnis. Aturan ini tercantum dalam Q.S. Al-Baqarah [2] ayat 195, Q.S. AlFurqan ayat [25] 67-68 dan ayat 72-73, Q.S. Al Isra [17] ayat 35, dan Q.S. Al-Qamar [54] ayat 49. Prakteknya dalam bisnis yaitu (Nawatmi, 2010): Tidak ada kecurangan dalam takaran dan timbangan serta penentuan harga berdasarkan mekanisme pasar yang normal.

Islam tentang mengatur tentang persaingan bisnis secara adil, salah satunya dalam konsep penentuan harga. Konsep harga dalam Islam harus dalam hal penentuannya harus dilakukan berdasrkan kekuatan pasar, yaitu kekuatan permintaan dan penawaran. Kesepakatan terjadinya permintaan dan penawaran tersebut harus terjadi secara sukarela.

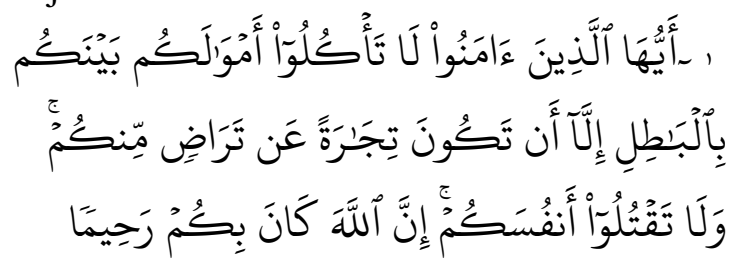

Artinya: Hai orang-orang yang beriman, janganlah kamu saling memakan harta sesamamu dengan jalan yang batil, kecuali dengan jalan perniagaan yang berlaku dengan suka sama-suka di antara kamu. Dan janganlah kати mетbunuh dirimu; sesungguhnya Allah adalah Maha Penyayang kepadamu. (Q.S An-Nisa' [4]:29)

Ayat di atas menekankan bahwa transaksi perdagangan harus dilakukan tanpa adanya paksaan, sehingga terbentuklah harga secara alamiah. Semua harga yang terkait dengan faktor produksi maupun produk barang itu sendiri bersumber pada mekanisme pasar seperti ini, karena penetapan harga tersebut diakui sebagai harga yang adil dan wajar (harga yang sesuai) (Jusmaliani, 2008).

Berdasarkan hasil wawancara dengan para narasumber yakni pedagang Pasar Besar Kota Palangka Raya didapati hasil bahwa pada dasarnya pedagang memahami tentang aksioma etika bisnis Islam pada point keadilan. Hal itu terlihat dari keterangan Pedagang RR yang menyatakan dalam berdagang tidak boleh mengurangi timbangan ataupun takaran. Pedagang RA juga menambahkan bahwa harus terdapat kesepakat masalah harga antar penjual dan pembeli. Pada prakteknya pun mereka mengatakan bahkan diantara beberapa narasumber menyatakan ikhlas tidak mengambil keuntungan sedikit pun dari hasil penjualan barang yang didapatkan dari pedagang lainnya untuk dijual kembali kepada pembeli. Hal tersebut mereka lakukan karena sudah ada kesepakatann harga di awal 
sedangkan pedagang lain memberikan harga di atas harga kesepakatan mereka, dan juga narasumber beranggapan bahwa merasa sudah cukup dengan keuntungan yang mereka dapatkan dari hasil penjualan barang sendiri. Kesimpulannya penentuan harga yang dilakukan oleh para pedagang ialah berdasarkan mekanisme pasar yang normal.

\section{3) Kehendak Bebas}

Pandangan Islam tentang kebebasan manusia yaitu manusis dianugerahi potensi untuk berkehendak dan memilih di antara pilihan-pilihan yang beragam, namun kebebasan itu tidak dalam kategori bebas sebebasnya sebagaimana kebebasan yang dimiliki oleh Allah SWT. Dengan kehendak bebasnya yang relatif (nisbi), manusia bisa saja menjatuhkan pilihan pada yang "benar", dan pada saat yang lain pada pilihan yang "salah". Hanya saja dalam Islam, anugerah Allah SWT bergantung pada pilihan awal manusia terhadap yang "benar". Inilah dasar etika yang sangat dijunjung tinggi dalam Islam. Perlu disadari oleh setiap muslim, bahwa dalam situasi apapun, dirinya dibimbing oleh aturan-aturan dan prosedurprosedur yang didasarkan pada ketentuanketentuan Allah SWT dalam syariat-Nya yang dicontohkan melalui Rasul-Nya. Oleh karena itu "kebebasan memilih" dalam hal apapun, termasuk dalam bisnis misalnya, harus dimaknai kebebasan yang tidak kontra produksi dengan ketentuan syariat yang sangat mengedepankan ajaran etika (Djakfar, 2012).

Berdasarkan prinsip ini, para pelaku bisnis mempunyai kebebasan untuk membuat perjanjian, termasuk menepati atau mengingkari janji. Namun seorang muslim yang percaya pada kehendak Allah SWT, akan memuliakan semua janji yang dibuatnya dengan siapapun. Selain itu, Indikator dari prinsip inii alah tidak menjelek-jelekkan bisnis orang lain agar orang membeli kepadanya, tidak melakukan ihtikar, tidak semena-mena dan lain sebagainya (Ahmad, 2001).

Para Pedagang Pasar Besar Kota Palangka Raya khususnya Pedagang RA menyebutkan bahwa etika yang dipahami ialah selalu menepati janji, misalnya ada orang yang pesan barang kemudian kita janjikan barang tersebut akan ada keesokan harinya maka sebagai pedagang harus menetapi janji tersebut dengan cara mencarikan sedapat mungkin barang yang dikehendaki oleh pembeli tersebut. Selain itu Pedagang RA juga menambahkan bahwa dalam transaksi jual beli kita tidak boleh memaksa pembeli untuk membeli dagangan, hal ini dikarenakan pembeli memiliki kebebasan dalam memutuskan hendak membeli ataupun tidak, yang boleh kita lakukan selaku pedagang hanya menawarkan barang bukan memaksa untuk membeli (RA, 2020). Kemudian juga Pedagang KH, RR dan juga RA sepakat mengatakan bahwa tidak boleh menjelek-jelekkankan pedagang lain, dan tidak boleh merasa saling bersaing antar sesama pedagang meskipun barang yang dijual relatif sama apabila jika berbeda. Pada hakikatnya pedagang memahami bahwa rezeki diatur oleh Allah SWT sehingga meminimalisir terjadinya persaingan antar pedagang karena adanya pemahaman tentang hal tersebut.

\section{4) Pertanggung Jawaban}

Setap manusia dalam hal ini pedagang bertanggung jawab atas segala tindakannya dalam berdagang. Menurut Quth prinsip pertanggungjawaban adalah tanggung jawab yang seimbang dalam segala bentuk dan ruang lingkupnya, antara jiwa dan raga, antara orang dan keluarga, antara individu dan masyarakat serta antara masyarakat yang satu dengan masyarakat lainnya. Aplikasi prinsip pertanggungjawaban dalam bisnis yaitu (Nawatmi, 2010): Pertama, Upah harus disesuaikan dengan UMR (upah minimum regional). Kedua, Economic return bagi pemberi pinjaman modal harus dihitung berdasarkan perolehan keuntungan yang tidak dapat dipastikan jumlahnya dan tidak bisa ditetapkan terlebih dahulu seperti dalam sistem bunga. Ketiga, Islam melarang semua transaksi alegotoris seperti gharar, sistem ijon, dan sebagainya.

Implementasi pemahaman pedagang terkait prinsip tanggungjawab ialah tidak boleh menipu, tidak menjual barang yan dilarang serta tidak boleh menjual barang yang cacat. Sebagaimana kita bahwa Rasulullah SAW mencontohkan sikap jujur dalam berdagang, yakni menyampaikan produk yang kita tawarkan kepada pembeli dengan sebenar-benarnya tanpa ada unsur penipuan. Sebagaimana keterangan Pedagang 
RA yang mengatakan bahwa tidak boleh berdusta dalam berdagang. Tidak boleh berdusta disini maksudnya ialah harus menyampaikan kondisi barang sebagai mana adanya dtidak ditambah-tambahkan atau dikurangi. Pedagang NA juga menambahkan bahwa dalam berdagang tidak boleh menipu. Begitu pula Pedagang RR menyebutkan bahwa etika dalam berdagang ialah tidak boleh mengurangi timbangan (NA, 2020; RA, 2020; RR, 2020). Hal-hal tersebut di atas merupakan Etika Bisnis Islam yang dilakukan oleh pedagang sebagai bentuk tanggung jawab agar menjadi sebagai pedagang yang terpercaya. Ketika pembeli sudah merasa percaya dengan pedagang berarti pembeli tersebut merasa puas dan akan memunculkan keinginan untuk berbelanja kembali di toko pedagang tersebut (menjadi pelanggan)

\section{5) Kebenaran (Kebajikan dan Kejujuran)}

Kebenaran dalam hal bisnis berarti sebagai niat, sikap dan perilaku benar, yang meliputi proses akad (transaksi), proses mencari atau memperoleh komoditas, proses pengembangan maupun dalam proses upaya meraih dan menetapkan keuntungan. Termasuk ke dalam kebajikan dalam bisnis adalah sikap kesukarelaan dan keramahtamahan, kesukarelaan dalam pengertian, sikap suka-rela antara kedua belah pihak yang melakukan transaksi, kerja sama atau perjanjian bisnis. Hal ini ditekankan untuk menciptakan dan menjaga keharmonisan hubungan serta cintamencintai antar mitra bisnis. Sedangkan keramahtamahan merupakan sikap ramah dan toleran, baik dalam menjual, membeli maupun menagih. Adapun kejujuran adalah sikap jujur dalam semua proses bisnis yang dilakukan tanpa adanya penipuan sedikitpun.

\footnotetext{
Pada prakteknya para Pedagang Pasar Besar Kota Palangka Raya telah mengimplementasikan prinsip kebenaran dalam usahanya sebagaimana disampaikan oleh Pedagang $\mathrm{KH}$ yang membolehkan pembeli untuk mengembalikan (menukar) barang yang dibeli di tokonya asalkan cepat dan barang tersebut memang belum dipakai dan bagi pembeli diharapkan juga jangan sampai berbohong ketika mau menukar barang (KH, 2020). Kemudian semua
}

narasumber sepakat bahwa dalam melayani pembeli harus bersikap jujur, ramah, sopan, lemah-lembut dan juga tersenyum (jangan bermuka masam) ketika melayani pembeli. Selain itu juga harus bersikap responsif terhadap pembeli dimana ketika ada pembeli yang berkunjung ke toko kita maka kita harus cepat tanggap menanyakan kepada pembeli tentang kebutuhan atau keinginannya, baru kemudian menawarkan barang yang sesuai dengan maksud pembeli. Pedagang juga harus bersikap sabar dalam melayani pembeli meskipun terkadang ada pembeli yang banyak maunya (cerewet).

\section{Kendala Implementasi Spirit Ta'awun Dalam Strategi Pemasaran Pedagang Pasar Besar Kota Palangka Raya}

Ketika menjalankan sebuah usaha ataupun perdagangan tidak selalu sesuai dengan apa yang diharapkan kadang kala terjadi berbagai macam kendala yang harus dihadapi oleh para pengusaha atau pun pedagang. Sebagaimana dipaparkan dalam pembahasan sebelumnya diketahui bahwa bentuk implementasi spirit Ta'awun dalam strategi pemasaran pedagang pasar besar kota palangka raya ialah terdapat pada bentuk marketing mix 4P, yaitu Product, Price, Place dan Promotion. Dalam hal mengimplementasikan spirit Ta'awun dalam kegiatan tersebut pun tidak serta merta bisa dilakukan dengan mudah karena ada berbagai alasan yang menjadi kendala dalam implementasinya. Untuk itu peneliti secara garis besar membagi bentuk kendala implementasi spirit Ta'awun dalam strategi pemasaran Pedagang Pasar Besar Kota Palangka Raya dari dua sisi yaitu kendala dari sisi pedagang dan kendala dari sisi pembeli.

Kendala Implementasi Spirit Ta'awun dalam Strategi Pemasaran Pedagang Pasar Besar Kota Palangka Raya terbagi yang pertama yakni kendala dari sisi pedagang terdapat berbagai macam kendala sesuai dengan hasil observasi dan juga wawancara yang dilakukan oleh peneliti yaitu Pedagang KH menyatakan bahwa ada sebagian pedagang lain yang tidak mau memberikan barangnya untuk dijual lagi dengan berbagai macam alasan seperti barangnya susah dicari, sudah dipesan oleh orang atau pun beralasan barang tersebut untuk pajangan di tokonya 
dan alasan-alasan lainnya. Pedagang KH juga menambahkan terkadang bisa juga pedagang lain tersebut mau meberikan barang tetapi dengan harga yang sama dengan atau bahkan lebih tinggi dari harga pasaran sehingga pedagang awal tidak bisa mendapatkan keuntungan ketika ingin menjual barang tersebut kepada calon pembeli (KH, 2020). Pernyataan tersebut juga selaras dengan pendapat Pedagang RA yang mengatakan ada beberapa pedagang tidak mau diambil barangnya. Namun uniknya Pedagang $\mathrm{KH}$ juga menambahkan bahwa pedagang yang tidak mau memberikan barang kepadanya tersebut kadang kala suatu waktu juga datang kepadanya untuk membeli barang untuk dijual kembali kepada calon pembeli dengan setengah memaksa (KH, 2020). Hal ini menunjukkan bahwa ada sebagian pedagang yang ingin menang sendiri, hanya menginginkan dagangannya sendiri yang laku dan tidak mau berbagi keuntungan dengan pedagang lain dengan cara menolak memberikan barang ketika pedagang lain membutuhkan.

Kendala dari sisi pembeli yaitu berdasarkan pernyataan Pedagang RR bahwa terkadang pembeli kabur ketika sedang mencarikan barang yang didinginkan oleh pembeli tersebut, atau bisa juga pembeli membatalkan pembeliannya ketika barang sudah ada (RR, 2020). Hal yang sama juga disampaikan oleh Pedagang NA yang menyatakan bahwa ada pembeli yang tibatiba berubah pikiran untuk tidak jadi membeli barangnya ketika barang sudah diambilkan ke pedagang lain dengan alasan motif tidak cocok ataupun lainnya yang tidak jelas. Selanjutnya Pedagang RA juga menyatakan bahwa kendala dari sisi pembeli yaitu pembeli yang kabur saat diminta untuk menunggu atau pembeli yang mengatakan bahwa ingin ke tempat lain lebih dulu nanti akan balik lagi tetapi ditunggu sampai toko hampir tutup pun pembeli tersebut tidak kunjung datang kembali (RA, 2020). Begitu pula pernyataan dari Pedagang MI yang menyatakan bahwa terkadang ada pembeli yang menyampaikan alasan-alasan yang kurang masuk akal ketika barang sudah diambilkan, misal sperti sulit membawa barang tersebut, lupa membawa uang, menanyakan kepada orang dulu (pesanan orang) atau bahkan ada pula pembeli yang malah menawar kembali harga barang tersebut padahal sudah terjadi kesepakatan harga di awal sebelum barang dicarikan.

\section{Kesimpulan}

Bentuk implementasi Spirit Ta'awun dalam Strategi Pemasaran Pedagang Pasar Besar Kota Palangka Raya dengan menerapkan konsep 4P yaitu: Product (Produk) dengan menyediakan berbagai macam produk yang merupakan kebutuhan maupun keinginan pembeli dan jika barang yang dicari oleh pembeli sedang habis ataupun kosong maka pedagang sedapat mungkin akan membantu mencarikan produk (barang) tersebut ke toko pedagang lain dengan tujuan untuk membantu pembeli agar tidak repot mencari-cari barang tersebut serta untuk membantu menjualkan barang pedagang lainnya. Price (harga), dengan memberikan harga yang terjangkau atau sesuai dengan harga pasaran meskipun barang yang dijual merupakan barang yang dibeli dari pedagang lainnya jadi secara otomatis keuntungan yang didapatkan hanya sedikit. Bahkan ada pula pedagang yang rela tidak mengambil keuntungan sama sekali sebagai bentuk tolong-menolong kepada pembeli dan pedagang lainnya. Place (Tempat) dengan melakukan transaksi penjualan di toko pedagang. Jadi ketika barang yang dicari pembeli kosong maka pedagang tersebut yang akan mencarikan ke pedagang lainnya, sedangkan pembeli cukup menunggu saja ketika barang dicarikan. Pada saat barang sudah didapatkan pedagang akan membawakan barang tersebut ke pembeli yang menunggu, sehingga tempat proses transaksi jual beli tetap berlangsung di toko si pedagang awal. Promotion (promosi), dengan cara menyampaikan kelebihan maupun kekurangan barang yang diperjualbelikan selain itu pedagang tidak hanya mempromosikan maupun memasarkan dagangannya sendiri tetapi juga memasarkan dagangan pedagang lain sebagai langkah untuk saling bekerja sama dan tolongmenolong sesama para pedagang dan juga kepada para pembeli dengan menggunakan metode Personal Selling dan Sales Promotion.

Kendala Implementasi Spirit Ta'awun dalam Strategi Pemasaran Pedagang Pasar Besar Kota Palangka Raya terbagi menjadi 
dua yaitu kendala dari sisi pedagang maupun kendala dari sisi pembeli. Dari sisi pedagang kendalanya ialah terkadang ada pedagang yang tidak mau memberikan dagangannya kepada pedagang lain untuk dijual kembali dengan alasan mau menjual sendiri (tidak mau berbagi keuntungan) barang tersebut ataupun dari segi harga ketika pedagang lainnya hendak menjual barangnya kepada sesama pedagang malah dengan harga yang lebih tinggi dari harga pasaran ataupun harga kesepakatan pedagang awal dengan pembeli. Sedangkan kendala dari sisi pembeli yaitu pembeli yang cerewet ketika sudah dicarikan produk yang diinginkan sebelumnya namun ketika barang sudah ada dia tiba-tiba malah mengeluarkan berbagai macam alasan yang tidak jelas dengan maksud tidak jadi membeli ataupun pembeli yang tidak sabar sehingga pergi begitu saja ketika barang sedang dicarikan.

\section{Daftar Pustaka}

Ahmad, M. (2001). Etika Bisnis Dalam Islam. Pustaka Al-Kautsar.

Alma, B. (2008). Kewirausahaan. Bandung: Alfabeta.

Djakfar, M. (2012). Etika Bisnis: Menangkap Spirit Ajaran Langit dan Pesan Moral Ajaran Bumi. Penebar PLUS+.

Jusmaliani. (2008). Bisnis Berbasis Syariah. Jakarta: Bumi Aksara.

KH. (2020, Oktober 3). Wawancara.

Khoiruddin, M. (2018). Pendidikan Sosial Berbasis Tauhid dalam Perspektif Al-Qur'an. Aplikasia: Jurnal Aplikasi Ilmu-Ilmu Agama, 18(1), 51-61. https://doi.org/10.14421/aplikasia.v1 $8 \mathrm{i} 1.1385$

Labaso, S. (2018). Penerapan Marketing Mix sebagai Strategi Pemasaran Jasa
Pendidikan di MAN 1 Yogyakarta. MANAGERIA: Jurnal Manajemen Pendidikan Islam, 3(2), 289-311. https://doi.org/10.14421/manageria.2 018.32-05

MI. (2020, Oktober 3). Wawancara.

NA. (2020, Oktober 3). Wawancara.

Nawatmi, S. (2010). Etika Bisnis Dalam Perspektif Islam. Fokus Ekonomi, 9(1), 50-58.

Pane, D. N. (2018). Analisis Pengaruh Bauran Pemasaran Jasa Terhadap Keputusan Pembelian Teh Botol Sosro (Studi Kasus Konsumen Alfamart Cabang Ayahanda). JUMANT, 9(1), 13-25.

RA. (2020, Oktober 3). Wawancara.

RR. (2020, Oktober 3). Wawancara.

Rusmadi. (2016). Analisis Strategi Pemasaran Bisnis Modern. SYNTAX LITERATE Jurnal Ilmiah Indonesia, 01(03). Diambil dari http://jurnal.syntaxliterate.co.id/inde x.php/syntax-literate/article/view/47

Sedjati, R. S. (2015). Manajemen Strategis. Yogyakarta: Deepublish.

Sjaiful, M. (2014). Penegakan Asas Taawun Dalam Perjanjian Utang Piutang di Pegadaian Syariah. Kultura, 15(01).

Supriyanto, M., \& Taali, M. (2018). Pengaruh Bauran Pemasaran (Marketing Mix) terhadap Pengambilan Keputusan Menginap di The Sun Hotel Madiun. Epicheirisi: Jurnal Manajemen, Administrasi, Pemasaran Dan Kesekretariatan, 2(1), 13-21. 